\title{
PEMBUATAN PRODUK INSTAN MINUMAN HERBAL BIR PLETOK
}

\author{
(The Making Of Instant Herbal Drink Bir Pletok)
}

\author{
Hefni Henidar ${ }^{1}$, Pemta Tiadeka ${ }^{2}$ \\ Universitas Muhammadiyah Gresik ${ }^{1}$ \\ Universitas Muhammadiyah Gresik ${ }^{2}$ \\ Email: hefnihenidaralif@gmail.com ${ }^{1}$ \\ tia.deka1307@umg.ac.id ${ }^{2}$
}

\begin{abstract}
Nowaday, people have more attention for their health. They think healthy food or drink came from herbal plant. There are many ways to cultivate plant until they are ready to be harvested. UPT Materia Medica Batu is one of unit that managing plant from cultivate, harvest, making herbal product and analyxing those product. Bir Pletok is one kind of drink that made from ginger, cinnamon, lemongrass, clove, cardamom and secang wood. This herbal drink is believed can imcrease body fit. The purpose of this study is to formulate an acceptable herbal drink as bir pletok. Bir pletok is preparated into two formula (formula I and form ula II). The difference between those formula is composition of ginger and secang wood. Sensory analysis is done to determine the panel's acceptance include colour, taste and aroma characteristic. The result of this research is showed that bir pletok with formula I is getting good colour and taste. It came from secang wood that given interested red colour and low quantity of ginger so giving good taste. There is 15 panelis that participated to Sensory analysis. It can be conclude that 26,6\% panelis very liked bir pletok with formula II based on colour. Then 13,3\% said very like bir pletok with formula II depend on aroma and taste. This bir pletok formula II is better served hot or cold.
\end{abstract}

Key word : Bir pletok, ginger, secang, taste, colour, aroma

\section{PENDAHULUAN}

Saat ini, masyarakat memiliki orientasi maslaah kesehatan yang semakin baik. Pengobatan alami cenderung menjadi pilihan Peracikan jamu serbuk adalah proses pencampuran beberapa serbuk dari tanaman herbal yang memiliki beberapa senyawa aktif yang dapat saling mendukung untuk memaksimalkan khasiat dari pengobatan yang diinginkan. Indonesia merupakan negara yang kaya akan rempah-rempah. Materia Medica Batu merupakan salah satu Unit Pelaksana Teknis (UPT) dari Dinas Kesehatan Provinsi Jawa Timur yang berlokasi di Kota Batu yang mengelola tanaman untuk kesehatan termasuk tanaman herbal dan rempah-rempah. Salah satu olahan produk pangan berbahan rempah-rempah adalah minuman herbal. Minuman tersebut dapat meningkatkan kebugaran dan kesehatan tubuh. Contoh minuman herbal khas Indonesia yaitu wedang jahe, wedang ronde, angsle, wedang secang dan bir pletok (Ishartani.,dkk,2012)

Bir pletok merupakan minuman fungsional dari rempah-rempah yang memiliki beragam khasiat. Minuman herbal tersebut memiliki potensi untuk untuk dikomersialkan karena pembuatannya sudah dalam bentuk minuman instan siap saji. Bir pletok merupakan minuman yang terdiri dari banyak rempah-rempah dengan komponen utamanya adalah jahe sebagai penguat aroma dan rasa. Pada dasarnya, minuman bir pletok memiliki banyak variasi rasa namun komponen utamanya adalah jahe dan secang. Pada penelitian ini akan dilakukan modifikasi dua jenis formula produk instan bir pletok yaitu variasi komposisi jahe sedikit dan kayu secang yang lebih banyak pada formula II. Selanjutnya, minuman herbal tersebut akan diuji hedonic pada beberapa panelis untuk mengetahui variasi minuman instan yang paling tepat untuk bir pletok.

\section{II.TINJAUAN PUSTAKA}

Berdasarkan proses pengembangannya, tanaman obat atau obat tradisional dapat dibagi menjadi 3 jenis yaitu tetap tradisional, produk terstandar, dan produk mencapai zat kimia tunggal (Depkes,2014). Diasmping itu, WHO juga merekomendasikan obat tradisonal dalam pemeliharaan kesehatan (WHO,2005). Beberapa penelitian yang telah dilakukan terhadap tanaman obat, maka dapat membantu dalam pemilihan bahan baku obat tradisional (Sari,2008). Minuman merupakan semua hal yang dikonsumsi dan dapat 
menghilangka rasa haus(Gilitasha,2018). Bir pletok adalah minuman khas Betawi yang terdiri dari campurna rempah-rempah termasuk jahe dengan warna merah yang berasal dari kayu secang.

Adanya beberapa variasi formula resep bir pletok yang ada di masyarakat Betawi memerlukan proses seleksi untuk memilih formula bir yang paling disukai kemudian dilakukan uji sensori. Bir pletok yang terpilih selanjutnya dikembangkan dalam hal kepraktisan kemasan penyimpanan. Saat ini sudah dikembangkan bir pletok dalam bentuk instan serbuk tetapi kualitas rasa dan aroma masih kurang. Pembuatan konsentrat melalui proses pemekatan volume sebesar seperempat kali dengan waktu perebusan 1 jam dan skala penelitian $1 / 2$ resep maka dapat menghasilkan rasa dan aroma bir pletok yang tanpa pemekatan (Muliani, 2017).

Beberapa penelitian tentang bir pletok yang sudah dikomersialkan telah dilakukan oleh (Andriany,2009). Berdasarkan hasil penelitian Wiguna (2011) dapat diketahui bahwa penurunan kapasotas antioksidan pada bir pletok disebabkan oleh suhu dan transparansi kemasan. Semakin tinggi suhu penyimpanan maka kadar antioksidan juga makin menurun. Selanjutnya, transparansi kemasan yang tinggi juga akan mengakibatkan berkurangnya antioksidan tersebut sedangkan kriteria penerimaan konsumen terhadap bir pletok sebanding dengan kapasitas antioksidan di dalamnya.

\section{III.Metode PENELITIAN}

\subsection{Alat dan Bahan}

Alat yang digunakan dalam penelitian ini adalah wajan, blender, baskom, pisau, panci, kain saring, sendok, spatula, ayakan dan kompor. Sedangkan, bahan-bahan yang digunakan dalam pembuatan bir pletok yaitu jahe emprit, serai, cengkeh, kayu manis, pala, kapulaga, secang, gula pasir, dan air. Penelitian ini dilakukan di UPT Materia Medica Batu Malang.

\subsection{Prosedur Kerja}

Prosedur kerja pembuatan bir pletok mengacu pada penelitian Ishartani dkk.,(2012). Jahe emprit dibersihkan kemudian dirajang dan dibelnder hingga halus. Air ditambahkan pada blender jahe emprit.
Jahe diperas kemudian disaring. Dimasukkna bahan kayu manis, serai, kayu secang, kapulaga, dan buah pala. Semua bahan diaduk dan ditunggu hingga mendidih. Hasil rebusan disaring dan ampas dibuang. Hasil saringan dipindahkan ke wajan dan dimasukkan gula pasir ke dalamnya. Campuran diaduk hingga membentuk kristal. Lanhkah berikutnya adalah menghancurkan kristal dan diayak hingga diperoleh instan bir pletok. Tahap finishing dilakukan dengan memasukkan instan tersebut ke dalam kemasan kemudian diberikan label. Penelitian ini dilakukan menggunakan 2 formula yaitu:

Tabel 2.1 Formulasi Bir Pletok

\begin{tabular}{|c|c|c|c|}
\hline \multirow{2}{*}{ No } & \multirow{2}{*}{ Nama Bahan } & \multicolumn{2}{|c|}{ Jumlah } \\
\cline { 3 - 4 } & & Formula I & Formula II \\
\hline 1 & Jahe & $500 \mathrm{~g}$ & $350 \mathrm{~g}$ \\
\hline 2 & Kapulaga & $11 \mathrm{~g}$ & $10 \mathrm{~g}$ \\
\hline 3 & Pala & $2,5 \mathrm{~g}$ & $5 \mathrm{~g}$ \\
\hline 4 & Serai & $70 \mathrm{~g}$ & $80 \mathrm{~g}$ \\
\hline 5 & Kayu Manis & $39 \mathrm{~g}$ & $60 \mathrm{~g}$ \\
\hline 6 & Cengkeh & $6 \mathrm{~g}$ & $6 \mathrm{~g}$ \\
\hline 7 & Kayu Secang & $60 \mathrm{~g}$ & $75 \mathrm{~g}$ \\
\hline 8 & Gula & $500 \mathrm{~g}$ & $500 \mathrm{~g}$ \\
\hline 9 & Air & $700 \mathrm{ml}$ & $700 \mathrm{ml}$ \\
\hline
\end{tabular}

\section{HASIL DAN PEMBAHASAN}

Pada penelitian ini dilakukan variasi formulasi untuk melihat hasil produk yang paling bagus dan dilanjutkan pada uji hedonic. Perbedaan antara formula I dan II terletak pada jumlah bahan yang digunakan. Hasil akhir formula I tidak sesuai dengan produk ayng diharapkan ditinjau dari segi warna jamu instan yang dihasilkan tidak sesuai karena kayu secang. Warna yang terbentuk kurang menarik yang ditunjukkan dengan hasil warnanya sedikit kecoklatan. Disamping itu, dari segi rasa yang dihasilkan juga kurang sesuai karena jahe emprit yang digunakan dalam jumlah yang banyak. Hal ini menyebabkan rasa dari jahe emprit menutupi rasa dari bahan-bahan lain yang digunakan. Selanjutnya, fenomena tersebut mengakibatkan rasa jamu instan formula 1 lebih dominan rasa jahe.

Hasil modifikasi pada formula II menunjukkan bahwa warna yang dihasikan menarik karena kayu secang yang digunakan lebih banyak dibandingkan dengan formula I. Disamping itu, formula II juga kaya akan rasa dari berbagai rempah - rempah, sehingga produk bir yang dihasilkan tidak dominan pada rasa jahe emprit seperti yang dihasilkan pada formula I. 
Hasil akhir percobaan formula II bir pletok menunjukkan hasil yang baik ditandai dengan warna, rasa dan bau yang sesuai dengan yang diharapkan. Warna bir pletok formula II lebih menarik dari formula I karena jumlah kayu secang yang digunakan pada formula II lebih banyak. Untuk mengetahui formula mana yang paling disukai oleh masyrakat maka kami melibatkan 15 panelis untuk melakukan uji hedonik pada formula I dan II.

Produk bir pletok dilakukan uji hedonik terhadap 15 panelis. Uji tersebut meliputi bau, warna dan rasa. Produk instan bir pletok dapat disajikan dalam keadaan dingin dan panas. Penyajian bir pletok dalam keadaan panas atau dingin mendapatkan respon yang berbeda-beda dari setiap panelis. Formula I dan II disajikan dalam keadaan panas, sedangkan formula II disajikan dalam keadaan panas dan dingin. Berdasarkan hasil uji hedonic diperoleh hasil bahwa warna produk bir pletok pada formula I kurang menarik dan rasa dari jahenya sangat kuat sehingga pada saat diminum terasa pedas. Hal tersebut mengakibatkan adanya penutupan rasa terhadap bahan lainnya. Disamping itu, produk formula II dapat disajikan dalam keadaan panas dan dingin. Kemudian perlu penambahan jahe untuk menambah rasa pedas agar penyajian dalam keadaan dingin lebih segar.

Tabel 4.1 Hasil uji hedonik dari segi warna

\begin{tabular}{|l|c|c|c|c|c|c|}
\hline \multirow{2}{*}{ No } & \multirow{2}{*}{$\begin{array}{c}\text { Sampel } \\
\text { uji }\end{array}$} & $\begin{array}{c}\text { Tidak } \\
\text { suka }\end{array}$ & $\begin{array}{c}\text { Kurang } \\
\text { suka }\end{array}$ & $\begin{array}{c}\text { Cukup } \\
\text { suka }\end{array}$ & Suka & $\begin{array}{c}\text { Sangat } \\
\text { suka }\end{array}$ \\
\hline 1 & Formula 1 & - & $53,3 \%$ & $46,7 \%$ & - & - \\
\hline 2 & Formula 2 & - & $6,7 \%$ & $6,7 \%$ & $60 \%$ & $26,6 \%$ \\
\hline
\end{tabular}

Tabel 4.2 Hasil Uji Hedonik daei Segi Bau

\begin{tabular}{|l|l|c|c|c|c|c|}
\hline \multirow{2}{*}{ No } & \multirow{2}{*}{$\begin{array}{c}\text { Sampel } \\
\text { uji }\end{array}$} & $\begin{array}{c}\text { Tidak } \\
\text { suka }\end{array}$ & $\begin{array}{c}\text { Kuran } \\
\text { g suka }\end{array}$ & $\begin{array}{c}\text { Cukup } \\
\text { suka }\end{array}$ & suka & $\begin{array}{c}\text { Sangat } \\
\text { suka }\end{array}$ \\
\hline 1 & $\begin{array}{l}\text { Formula } \\
1\end{array}$ & - & $13,3 \%$ & $40 \%$ & $40 \%$ & $6,7 \%$ \\
\hline 2 & $\begin{array}{l}\text { Formula } \\
2\end{array}$ & - & - & $20 \%$ & $66,7 \%$ & $13,3 \%$ \\
\hline
\end{tabular}

Tabel 4.3 Hasil Uji Hedonik Dari Segi Rasa

\begin{tabular}{|l|l|c|c|c|c|c|}
\hline \multirow{2}{*}{ No } & \multirow{2}{*}{$\begin{array}{c}\text { Sampel } \\
\text { uji }\end{array}$} & $\begin{array}{c}\text { Tidak } \\
\text { suka }\end{array}$ & $\begin{array}{c}\text { Kurang } \\
\text { suka }\end{array}$ & $\begin{array}{c}\text { Cukup } \\
\text { suka }\end{array}$ & suka & $\begin{array}{c}\text { Sangat } \\
\text { suka }\end{array}$ \\
\hline 1 & $\begin{array}{l}\text { Formula } \\
1\end{array}$ & - & $33,3 \%$ & $40 \%$ & $20 \%$ & $6,7 \%$ \\
\hline 2 & $\begin{array}{l}\text { Formula } \\
2\end{array}$ & - & $6,7 \%$ & $40 \%$ & $40 \%$ & $13,3 \%$ \\
\hline
\end{tabular}

Berdasarkan hasil penilaian yang diberikan oleh 15 panelis menunjukkan bahwa produk bir pletok dengan menggunakan formula 2 lebih banyak disukai dari segi warna dan rasa. Hasil perhitungan presentase keunggulan formula 2 yaitu untuk warna $60 \%$ dan untuk rasa $66,7 \%$.

Hasil uji hedonik warna menunjukkan bahwa nilai tertinggi terletak pada bir pletok formula 2 dengan warna merah jamu instan bir pletok yang berasal dari kayu secang. Kemudian, rasa yang dihasilkan dari formula 2 juga banyak disukai oleh panelis. Hal ini dimungkinkan karena pada formula 2 jumlah jahe emprit yang digunakan jumlahnya lebih sedikit dibanding dengan formula 1 sehingga bau yang dihasilkan cukup menarik. Di sisi lain, proses penyimpanan bir pletok juga harus diperhatikan. Kapasitas antioksidan minuman tersebut akan semakin menurun dengan bertambahnya waktu penyimpanan. Minuman instant bir pletok disimpan dalam wadah gelap pada suhu $30^{\circ} \mathrm{C}$ (Wiguna 2011).

\section{V.PENUTUP}

Berdasarkan hasil penelitian yang telah dilakukan maka dapat disimpulkan bahwa produk bir pletok dapat dibuat dengan formula utama jahe emprit dan kayu secang, Hasil uji hedonism menunjukkan bahwa formula II lebih banyak disukai panelis karena komposisi jahe emprit yagn digunakan lebih sedikit dan formulasi kayu secang yang tepat sehingga warna produk lebih menarik.

\section{DAFTAR PUSTAKA}

[1] Andriany, Anita.2008.Analisis Pendapatan Minuman Obat Tradisional Betawi Sari Jahe (Bir Pletok). Skripsi. Prodi Agribisnis Universitas Islam Negeri Syarif Hidayatullah Jakarta.

[2] Astuti, Nugroho Y. 2003. Laporan Penelitian. Jakarta : Badan Litbangkes

[3] Dalimartha, S. 2005. Atlas Tumbuhan Obat Indonesia Jilid 1. Trubus Agriwidya. Jakarta. 170 hlm.

[4] Gilitasha, Andre. 2018. Pembuatan Bir Pletok Dengan Menggunakan Reverse Spherification Method Sebagai Inovasi Produk Berkelanjutan. Karya tulis Sekolah Tingginpariwisata Trisakti.

[5] Ishartani,D., Kawiji, dan Lia U.K.2012. Produksi Bir Pletok Antioksidan. Jurnal Teknologi Hasil Pertanian Vol. V No.2.

[6] Muliani, Lila. 2017. Mempromosikan Bir Pletok Sebagai Minuman Khas Betawi Melalui Penyajian 
Sebagai Welcome Drink. BIJAK Majalah Ilmiah Institut STIAMI Vol 14 No.02

[7] Sari, Lusia O.R.K. 2006.Pemanfaatan Obat Tradisional Dengan Pertimbangan Manfaat dan Keamanannya. Majalah Ilmu Kesehatan vol III No.1 ISSN 1693-9883.

[8]WHO, 2005. National Policy on Traditional Medicine and Regulation of Herbal Medicines, Report of a WHO global survey, Geneva

[9] Wiguna, Daniel.2011. Pengaruh Suhu dan Transparansi Kemasan Terhadap Stabilitas Kapasistas Antioksidan Sebagai Parameter Umur Simpan Bir Pletok. Skripsi. Fakultas Teknologi Pertanian IPB 
